\title{
Effect of Heat Stress on Production of Mediterranean Dairy Sheep
}

\author{
R. Finocchiaro, ${ }^{1}$ J. B. C. H. M. van Kaam, ${ }^{1,2}$ B. Portolano, ${ }^{1}$ and I. Misztal ${ }^{3}$ \\ ${ }^{1}$ Department S.En.Fi.Mi.Zo.-Animal Production Section, University of Palermo Viale delle Scienze-Parco d'Orleans, \\ 90128 Palermo, Italy \\ ${ }^{2}$ Istituto Zooprofilattico Sperimentale della Sicilia "A. Mirri", Via G. Marinuzzi 3, 90129 Palermo, Italy \\ ${ }^{3}$ Animal and Dairy Science Department, University of Georgia, Athens 30605
}

\section{ABSTRACT}

A study on heat stress in Mediterranean dairy sheep was undertaken with the objective to examine the relationship between milk production and heat stress, to estimate the additive genetic variances of milk production traits and heat tolerance, and to investigate the possibility of future selection for increased heat tolerance. Production data included 59,661 test-day records belonging to 6624 lactations of 4428 lactating ewes from 17 flocks collected from 1994 through 2003. The traits investigated were daily milk yield, fat and protein percentage, and daily yield of fat-plus-protein. The pedigree file consisted of 5306 animals; in addition to the 4428 animals with records, 188 male and 690 female ancestors were included. Heat stress was modeled by using data from a weather station. Apart from the effects of the weather conditions of the milk recording test-day, the effects of the preceding 1,2 , and $3 \mathrm{~d}$ were determined. Because longer periods of heat stress might have a more severe effect than shorter periods, 2-, 3-, and 4-d periods were also considered, by averaging the weather data measurements. Fixed regression analyses were based on models that included effects of flock nested within year of test-day, DIM (days in milk) class $\times$ parity class, and several types of weather indicators. The preferred model using the temperature-humidity index (THI) gave a smoother pattern than did the model with temperature $\times$ humidity interaction. Both daily milk and fat-plusprotein yield appeared to decrease at THI $\geq 23$, in all periods considered. Based on the 4-d period, yield decreased for each unit increase of THI above 23 [-62.8 g/unit $(-4.2 \%)$ for daily milk yield and $-8.9 \mathrm{~g} / \mathrm{unit}$ $(-4.9 \%)$ for daily fat-plus-protein yield]. Fat and protein percentages appeared to be unaffected by heat stress. A test-day repeatability model was applied for

Received November 23, 2004.

Accepted January 25, 2005.

Corresponding author: Raffaella Finocchiaro; e-mail: rfino@ unipa.it. estimation of genetic parameters. The genetic correlations between the general additive effect and the additive effect of heat tolerance were negative (approximately -0.8 ) for both daily milk and fat-plus-protein yields in all periods considered. Therefore, milk yield is antagonistic with heat tolerance, and selection only for increased milk production will reduce heat tolerance.

(Key words: heat stress, genotype-environment interaction, temperature-humidity index, dairy sheep)

Abbreviation key: $\mathbf{R H}=$ daily average relative humidity, $\mathbf{T}=$ daily maximum temperature, $\mathbf{T H I}=$ temperature-humidity index.

\section{INTRODUCTION}

Worldwide production of milk sheep is estimated around 8,000,000 tons per year, a small amount compared with the almost 500,000,000 tons of milk produced by dairy cattle. The European Mediterranean countries (Portugal, Spain, France, Italy, and Greece) account for almost $11 \%$ of the world sheep population. However, $67 \%$ of all dairy sheep production is concentrated in the Mediterranean region, whereas the same area accounts for only $15 \%$ of the dairy cattle production (FAO, 1997). These statistics show the importance of dairy sheep production in the Mediterranean area. This area is characterized by exposure to considerable heat from 3 to 6 mo annually, depending on the specific region. High ambient temperature, with high direct and indirect solar radiation, wind speed, and relative humidity cause the effective temperature of the environment to often exceed the thermoneutral zone of the animals (5 to $25^{\circ} \mathrm{C}$; McDowell, 1972), leading to heat stress (Bianca, 1962; Finch, 1984; Hayes et al., 2003). Heat stress is one of the limiting factors in dairy production in hot climates (Johnson et al., 1962) and is hard to account for by management in farming systems that practice semiextensive grazing. Mediterranean dairy sheep, for example, are usually outside during the entire summer season and are usually kept indoors only during winter nights or lambing. In addition to milk quantity, milk composition and quality might be 
affected by heat stress. These latter factors are important, considering that sheep milk production is directed toward cheese making. Some studies (Ames et al., 1971; Lowe et al., 2001; Sevi et al., 2001; Srikandakumar et al., 2003) on sheep heat stress investigated changes in rectal temperatures, respiration rates, or volumes of air inhaled, and other physiological functions. Unfortunately, such measurements are costly and not feasible on a large scale in practical farming circumstances, which leads to insufficient data quantity, especially for genetic studies. To overcome this problem, a novel approach was developed by Ravagnolo et al. (2000) where data from the National Dairy Cattle recording system was combined with weather information obtained from numerous weather stations across the state of Georgia (US).

In this work, the methodology of Ravagnolo et al. (2000) was applied to dairy sheep. The study was performed on Valle del Belice dairy sheep reared in Sicily. The lambing season of this breed lasts all year, starting in July and finishing in the following June, but with few lambings in May and June. Other dairy sheep breeds often have 2 distinct lambing seasons with mature ewes lambing in September and October, and yearling ewes in January and February (Barillet and Boichard, 1994; Carta et al., 1995; Ligda et al., 2000). Valle del Belice farmers want to have some ewes lambing in July, before the August peak of lambing, because in this period the "Vastedda" cheese is produced; hence, lambing often occurs in the summer heat. In the typical Sicilian semiextensive system, few genetic connections between flocks are available, because of the lack of exchange of animals between flocks and due to the use of natural mating instead of artificial insemination. Several rams are traditionally present from March until December in a flock for natural mating, which results in offspring with uncertain sires. If farmers sell ewes to other producers, this usually occurs after the first lactation, which helps in creating connections.

The interest of our study was to investigate if, in the Mediterranean area, heat stress has an effect on dairy sheep performance. In particular, data from the Valle del Belice dairy sheep were analyzed, with the following aims: 1) to estimate the effects of hot weather conditions on milk production traits using information from a weather station, 2) to locate the point at which heat stress starts for dairy sheep, 3) to determine a heat stress function suitable for studying genetic tolerance against heat stress, and 4) to estimate the additive genetic variances of general and heat tolerance effects on milk production traits.

\section{MATERIALS AND METHODS}

\section{Data}

The initial data set consisted of 82,944 test-day records from different lactations of 5966 ewes. Records were divided into 3 parity classes (first, second, and $\geq$ third). These data were collected by the University of Palermo in 17 Valle del Belice dairy sheep flocks during the period from 1994 to 2003 . Production information included daily milk yield and fat and protein percentages. Subsequently, daily fat-plus-protein yield (g) was calculated. All ewes with fewer than 3 test-day records or a first test-day record more than $65 \mathrm{~d}$ postpartum were discarded from the analyses. Test-day records with daily milk yield $<200 \mathrm{~g}$ or $>4000$ $\mathrm{g}$ were eliminated from the data. The meteorological data set consisted of daily maximum temperature (T) and daily average relative humidity $(\mathbf{R H})$ on $3033 \mathrm{~d}$ out of $3133 \mathrm{~d}$ from January 1994 to July 2003. Meteorological data were provided by the "Ufficio Centrale di Ecologia Agraria", belonging to the Italian Ministry of Agriculture and Forestry. Only one meteorological weather station, located on the experimental farm of Pietranera, north of Agrigento (Sicily), was used because this weather station was close enough (at most $60 \mathrm{~km}$ ) to all the sheep farms included in the study. Daily milk production data and meteorological data were merged, resulting in 59,661 test-day records from 6624 lactations of 4428 lactating ewes in 17 flocks. The pedigree file consisted of 5306 animals; in addition to the 4428 animals with records, 188 male and 690 female ancestors were included. Among the 4428 animals with records, 2338 were dams having at least one daughter with a production record. Furthermore, 2076 ewes did not have any ancestor information, and of these ewes, 1502 did not have any offspring with production records. On average, the sires had 11.9 daughters ( $\mathrm{SD}=13.5$, range 1 to 99 ) in the 17 flocks under study. Table 1 shows a summary of the basic statistics of the final data set.

\section{Statistical Analyses}

To assess the influence of various weather circumstances, $\mathrm{T}, \mathrm{RH}$, and temperature-humidity index

Table 1. Description of production and weather data.

\begin{tabular}{lcc}
\hline Daily measurement & Mean $\pm \mathrm{SD}$ & Range \\
\hline Milk yield $(\mathrm{g})$ & $1361.3 \pm 703.3$ & $200-4000$ \\
Fat-plus-protein yield $(\mathrm{g})$ & $165.8 \pm 78.7$ & $14-567$ \\
Maximum temperature $\left({ }^{\circ} \mathrm{C}\right)$ & $22.5 \pm 7.5$ & $8.7-43.7$ \\
Average temperature $\left({ }^{\circ} \mathrm{C}\right)$ & $15.1 \pm 6.1$ & $3.3-31.4$ \\
Minimum temperature $\left({ }^{\circ} \mathrm{C}\right)$ & $7.8 \pm 5.3$ & $-3.7-24.0$ \\
Relative humidity $(\%)$ & $72.6 \pm 15.7$ & $22.7-100.0$ \\
Temperature-humidity index & $20.7 \pm 5.5$ & $9-32$ \\
\hline
\end{tabular}


(THI) were considered. The THI is commonly used as an indicator for the degree of stress on animals caused by weather conditions. The THI was calculated as proposed by Kelly and Bond (1971) by combining maximum temperature (in ${ }^{\circ} \mathrm{C}$ ) and average relative humidity $(\%)$ with the following expression:

$$
\mathrm{THI}=\{\mathrm{T}-[0.55 \times(1-\mathrm{RH})] \times(\mathrm{T}-14.4)\}
$$

In addition to the effects of the weather conditions on the day of milk recording, the effects of the weather 1,2 , and $3 \mathrm{~d}$ before the test-day were determined. These effects represented the lag effects of weather circumstances on near-future performance variables. Because longer periods of heat stress might have a more severe effect than shorter periods, the effects of the 2-, 3-, and 4-d periods before the test-day were also considered, by averaging daily $\mathrm{T}$ and $\mathrm{RH}$ measurements on these days. For longer periods, the THI was calculated using the average $\mathrm{T}$ and $\mathrm{RH}$ over all days with measurements in the period considered (i.e., rather than first calculating the THI for each day and then averaging these values). The use of the mean weather conditions across multiple days was chosen because 1) it resulted in a similar approach as with single days, and 2) the mean incorporated the severity of the weather conditions on individual days, whereas simply counting the number of heat-stress days during the period of interest would not have accounted for the severity during individual days.

Maximum temperature information was divided into 6 classes $\left(<24,24\right.$ to $<26^{\circ} \mathrm{C}, 26$ to $<28^{\circ} \mathrm{C}, 28$ to $<30^{\circ} \mathrm{C}, 30$ to $<33^{\circ} \mathrm{C}$, and $\geq 33^{\circ} \mathrm{C}$ ). Average $\mathrm{RH}$ was divided into 4 classes $(<50 \%, 50$ to $<65 \%, 65$ to $<80 \%$, and $\geq 80 \%$ ). Days in milk classes were defined as 1 class every $30 \mathrm{~d}$, starting at $\mathrm{d} 0$. This approach resulted in 8 DIM classes, as the last class included all DIM $\geq 210$.

Several models were applied using SAS PROC GLM (SAS Institute, 2000) to study the effect of $\mathrm{T}$ and $\mathrm{RH}$ on daily milk production traits. Model 1 was defined as:

$y_{i j k l m n}=\mu+\mathrm{FL}\left(\mathrm{Y}_{\mathrm{TD}}\right)_{i}+\mathrm{DIM}_{j} \times \mathrm{P}_{k}+\mathrm{T}_{l} \times \mathrm{RH}_{m}+e_{i j k l m n}$

where $y_{i j k l m n}$ is a measurement of test-day milk yield, fat percentage, protein percentage, or fat-plus-protein yield; $\mu$ is the fixed mean effect; $\mathrm{FL}\left(\mathrm{Y}_{\mathrm{TD}}\right)_{i}$ is the fixed effect of flock nested within year of test-day $i$ (87 levels); $\mathrm{DIM}_{j} \times \mathrm{P}_{k}$ is the fixed effect of DIM class $j$ by parity class $k$ interaction (24 levels); $\mathrm{T}_{l} \times \mathrm{RH}_{m}$ is the fixed effect of the T class $l$ by RH class $m$ interaction
(21 levels); $e_{i j k l m n}$ is the random residual term distributed as $\mathbf{e} \sim N\left(\mathbf{0}, \mathbf{I} \sigma_{e}^{2}\right)$. The model terms corresponding to the weather conditions changed depending which day or period was considered in the model.

Model 2 was the same as model 1, except that the $\mathrm{T} \times \mathrm{RH}$ interaction was replaced with the THI (24 to 27 , levels depending on the period). Subsequently, model 2 was also applied with reduced data sets (THI $\geq 23$ ), because our initial results showed a decline of production above a THI of 23 . The reduced data sets contained between 22,983 and 24,045 of the 59,661 records belonging to between 4204 and 4252 of the 4428 ewes with records depending on the period on which the THI was based.

To estimate the variances of the general and heat tolerance-related additive genetic effects on production, to estimate the genetic correlation between these effects, and to explore the possibility of future selection for increased heat tolerance, a test-day repeatability model (Ptak and Schaeffer, 1993) was applied only on traits clearly affected by heat stress (model 3). Model 3 was as follows:

$$
\begin{gathered}
y_{i j k l m n o}=\mathrm{FTD}_{i}+\mathrm{DIM}_{j} \times \mathrm{P}_{k}+a_{l}+\mathrm{f}\left(\mathrm{THI}_{m}\right) \times v_{l}+p_{n} \\
+\mathrm{f}\left(\mathrm{THI}_{m}\right) \times q_{n}+o_{k n}+\mathrm{f}\left(\mathrm{THI}_{m}\right) \times r_{k n}+e_{i j k l m n o}
\end{gathered}
$$

where $y_{i j k l m n o}$ is a measurement of test-day milk or fatplus-protein yield; $\mathrm{FTD}_{i}$ is the fixed effect of flock testday $i$ (983 levels); $\mathrm{DIM}_{j} \times \mathrm{P}_{k}$ is the fixed effect of DIM class $j$ by parity class $k$ (24 levels); $a_{l}$ is the general random additive genetic effect of animal $l$; $\mathrm{f}\left(\mathrm{THI}_{m}\right)$ is the heat stress function at THI of day $m$, defined as:

$$
\mathrm{f}\left(\mathrm{THI}_{m}\right)=\left\{\begin{array}{ll}
0 & \text { if } \mathrm{THI}<23 \\
(\mathrm{THI}-22) & \text { if } \mathrm{THI} \geq 23
\end{array} ;\right.
$$

$v_{l}$ is the random additive genetic effect of the heat tolerance of animal $l$ (both $a_{l}$ and $v_{l}$ have 5306 levels); $p_{n}$ is the general random permanent environmental effect of ewe $n ; q_{n}$ is the random permanent environmental effect of the heat tolerance of ewe $n ; p_{n}$ and $q_{n}$ are across lactations (both 4428 levels); $o_{k n}$ is the general random permanent environmental effect within parity class $k$ of ewe $n ; r_{k n}$ is the random permanent environmental effect of the heat tolerance within parity class $k$ of ewe $n ; o_{k n}$ and $r_{k n}$ are within lactation (both 6624 levels); $e_{i j k l m n o}$ is the random residual effect. The distributions of the random effects were specified as: 


$$
\left[\begin{array}{c}
\mathbf{a} \\
\mathbf{v} \\
\mathbf{p} \\
\mathbf{q} \\
\mathbf{o} \\
\mathbf{r} \\
\mathbf{e}
\end{array}\right] \sim N\left(\left[\begin{array}{ccccccc}
\mathbf{A} \sigma_{a}^{2} & \mathbf{A} \sigma_{a v} & 0 & 0 & 0 & 0 & 0 \\
\mathbf{A} \sigma_{a v} & \mathbf{A} \sigma_{v}^{2} & 0 & 0 & 0 & 0 & 0 \\
0 & 0 & \mathbf{I} \sigma_{p}^{2} & \mathbf{I} \sigma_{p q} & 0 & 0 & 0 \\
0 & 0 & \mathbf{I} \sigma_{p q} & \mathbf{I} \sigma_{q}^{2} & 0 & 0 & 0 \\
0 & 0 & 0 & 0 & \mathbf{I} \sigma_{o}^{2} & \mathbf{I} \sigma_{o r} & 0 \\
0 & 0 & 0 & 0 & \mathbf{I} \sigma_{o r} & \mathbf{I} \sigma_{r}^{2} & 0 \\
0 & 0 & 0 & 0 & 0 & 0 & \mathbf{I} \sigma_{e}^{2}
\end{array}\right]\right)
$$

where $\mathbf{A}$ and $\mathbf{I}$ are the numerator relationship matrix and identity matrices of appropriate orders. The genetic model was applied using only days and periods with THI $\geq 23$. Variance components were estimated with average information REML, using the program AIREMLF90 (Misztal et al., 2002). All lactations were used in the analyses, because this increased the number of connections between flocks due to the sale of ewes after the first lactation.

\section{RESULTS AND DISCUSSION}

The monthly patterns of the T, RH, THI, and lambing percentage in the 3 defined parity classes are shown in Figure 1. The figure shows a peak of lambing, mainly for mature ewes, in August when heat stress is common.

Daily milk and fat-plus-protein yield had a phenotypic correlation of 0.93 on days with heat stress (THI $\geq 23$ ). Table 2 shows the Pearson correlation coefficients of daily milk yield, fat and protein percentages, and daily fat-plus-protein yield with the weather conditions, including $\mathrm{T}, \mathrm{RH}$, and THI on the $4 \mathrm{~d}$ considered
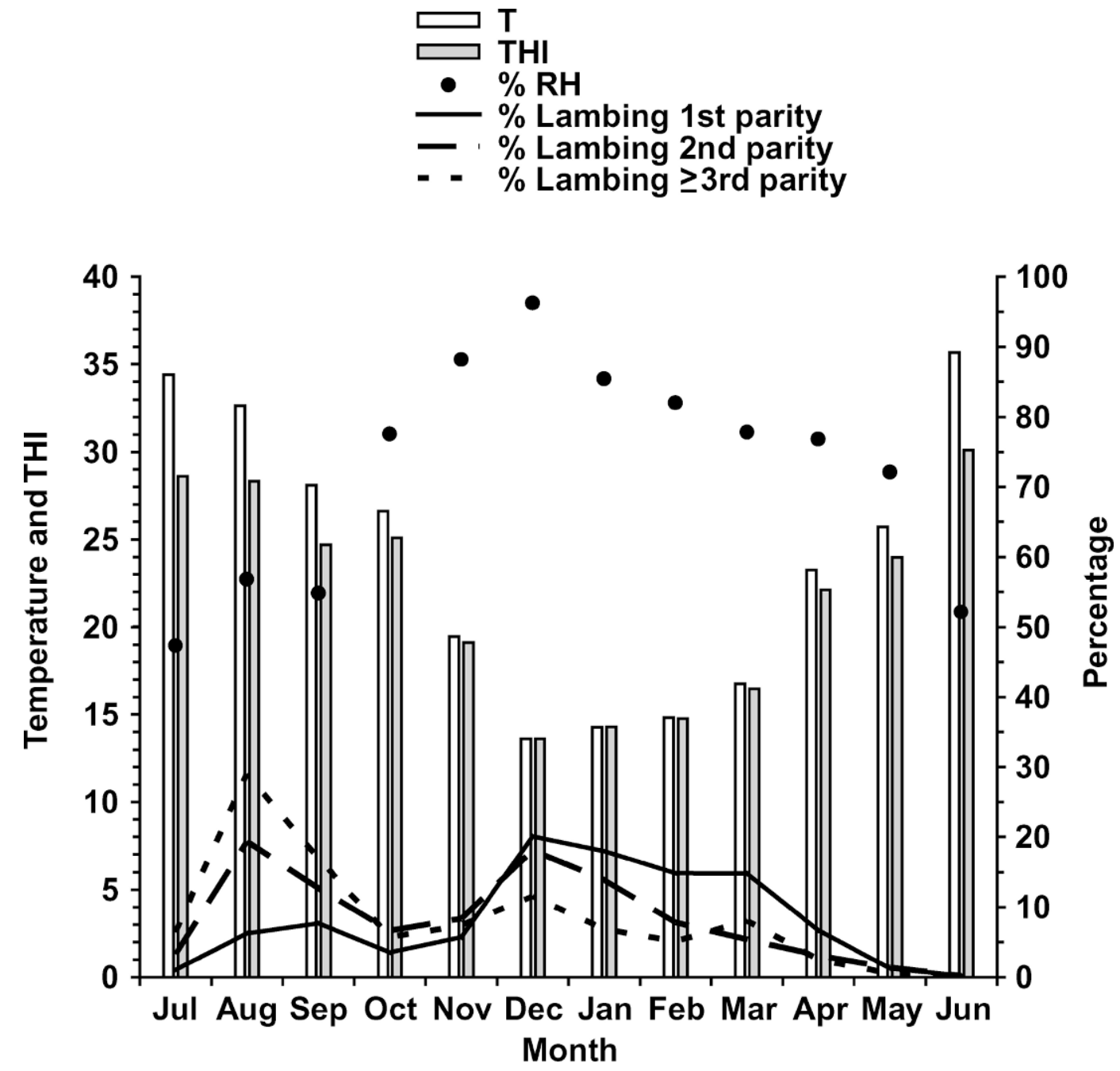

Figure 1. Maximum temperature $\left(\mathrm{T},{ }^{\circ} \mathrm{C}\right)$, temperature-humidity index $(\mathrm{THI})$, average relative humidity $(\mathrm{RH}, \%)$, and lambing percentages per parity class (first, second, and $\geq$ third) averaged over $10 \mathrm{yr}$ (1994 to 2003). 
Table 2. Pearson correlation coefficients between the traits daily milk yield, fat and protein percentage, daily fat-plus-protein yield, and the weather conditions on $4 \mathrm{~d}$, including only days with heat stress (THI $\geq 23$ ) and during 2 -, 3 -, and 4-d periods, including only periods with heat stress (THI $\geq 23$ ).

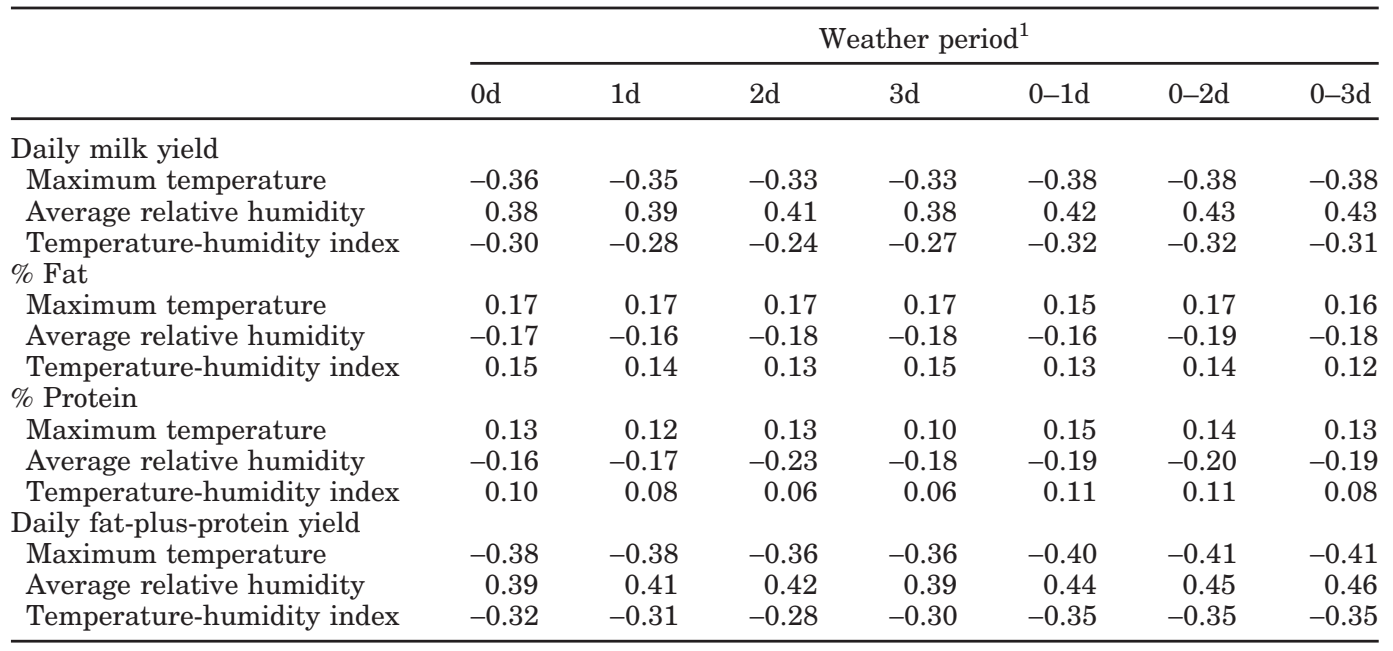

${ }^{1}$ Weather periods: $0 \mathrm{~d}, 1 \mathrm{~d}, 2 \mathrm{~d}$, and $3 \mathrm{~d}$ represent test-day, and 1,2 , and $3 \mathrm{~d}$ before test-day, respectively; $0-1 \mathrm{~d}, 0-2 \mathrm{~d}$, and $0-3 \mathrm{~d}$ represent the $2-, 3-$, and 4 -d periods ending on the test-day, respectively.

(test-day, 1, 2, and $3 \mathrm{~d}$ before) and during the 2-, 3-, and 4-d periods including only days or periods with heat stress (THI $\geq 23$ ). Daily milk and fat-plus-protein yields were consistently negatively correlated with $\mathrm{T}$ and THI. The magnitudes of these negative correlations were increased when $\mathrm{T}$ and THI for multipleday periods rather than single days were considered. Furthermore, daily milk and fat-plus-protein yield had positive correlations with $\mathrm{RH}$. Higher correlations were observed for longer periods than for single days. On the contrary, fat and protein percentages were

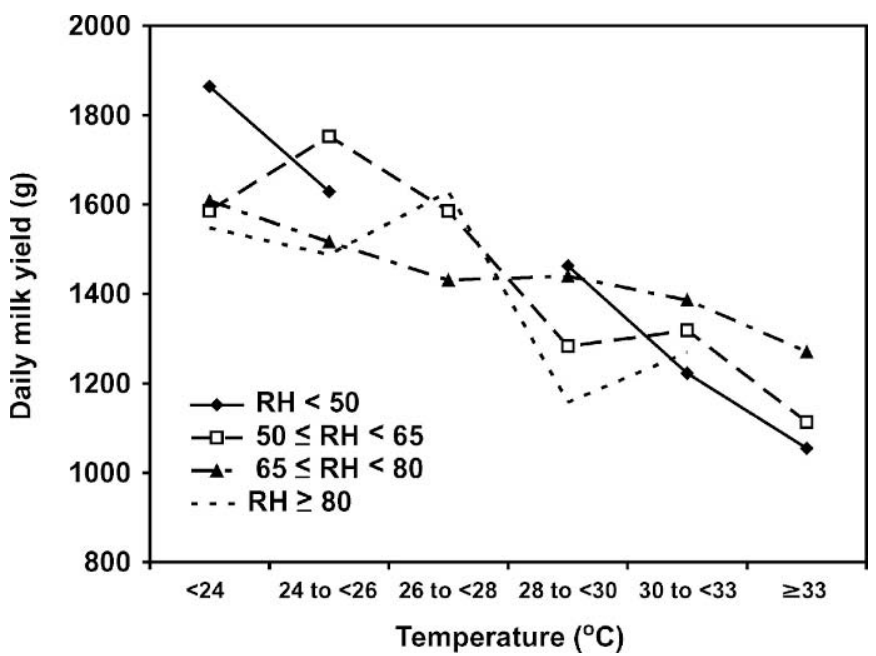

Figure 2. Effect of maximum temperature and average relative humidity ( $\mathrm{RH}$ ) (1 d before) on daily milk yield. Some maximum temperature-relative humidity combinations did not occur. weakly positively correlated with $\mathrm{T}$ and THI and weakly negatively correlated with $\mathrm{RH}$. In all periods, the correlation coefficients of the production traits with THI were always smaller than with $\mathrm{T}$ or with $\mathrm{RH}$. These results seem to confirm an effect of weather conditions on dairy sheep performance. Furthermore, these results confirm that weather station data can be useful for the detection of heat stress affecting dairy sheep production.

Figures 2 and 3 show the least squares means of daily milk and fat-plus-protein yields for all $\mathrm{T}$ classes

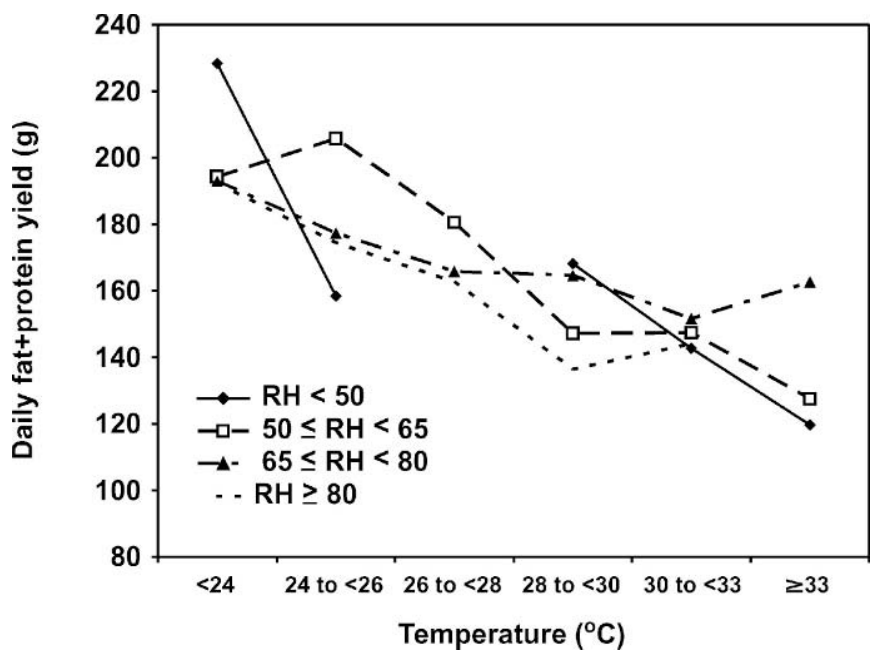

Figure 3. Effect of maximum temperature and average relative humidity $(\mathrm{RH})$ ( $1 \mathrm{~d}$ before) on daily fat-plus-protein yield. Some maximum temperature-relative humidity combinations did not occur. 


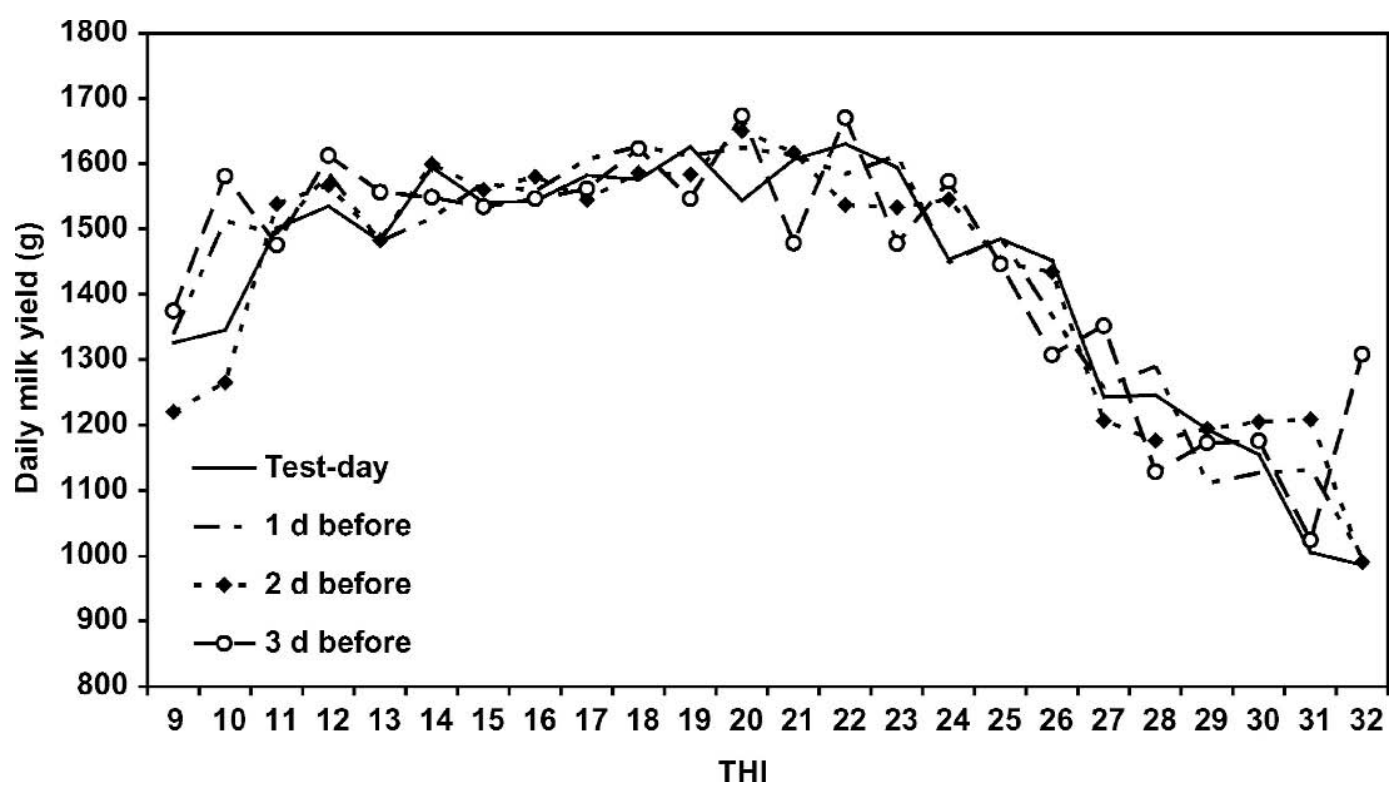

Figure 4. Relationship between the daily milk yield and the temperature-humidity index (THI) based on maximum temperature and average relative humidity in $4 \mathrm{~d}$ (test-day, and 1,2 , and $3 \mathrm{~d}$ before).

in the $4 \mathrm{RH}$ categories on the day before the milk recording. The combination of $26^{\circ} \mathrm{C} \leq \mathrm{T}<28^{\circ} \mathrm{C}$ and $\mathrm{RH}<50$ was never observed during the study. Both figures clearly show a decreasing trend in production with increasing $\mathrm{T}$. Yields tended to vary more between $\mathrm{T}$ classes within the same $\mathrm{RH}$ category than between $\mathrm{RH}$ categories within the same $\mathrm{T}$ class. This result suggests that high $\mathrm{T}$ is more important than high $\mathrm{RH}$ when considering the relationship between heat stress and yield. In fact, as the $\mathrm{T}$ exceeded $30^{\circ} \mathrm{C}$, the decline in yield was greatest when $\mathrm{RH}$ was low. As indicated in Table 2, RH had slightly higher (in magnitude) correlations with yield than $\mathrm{T}$, but correlations were positive. The relationships between yield and $\mathrm{T}$ did not

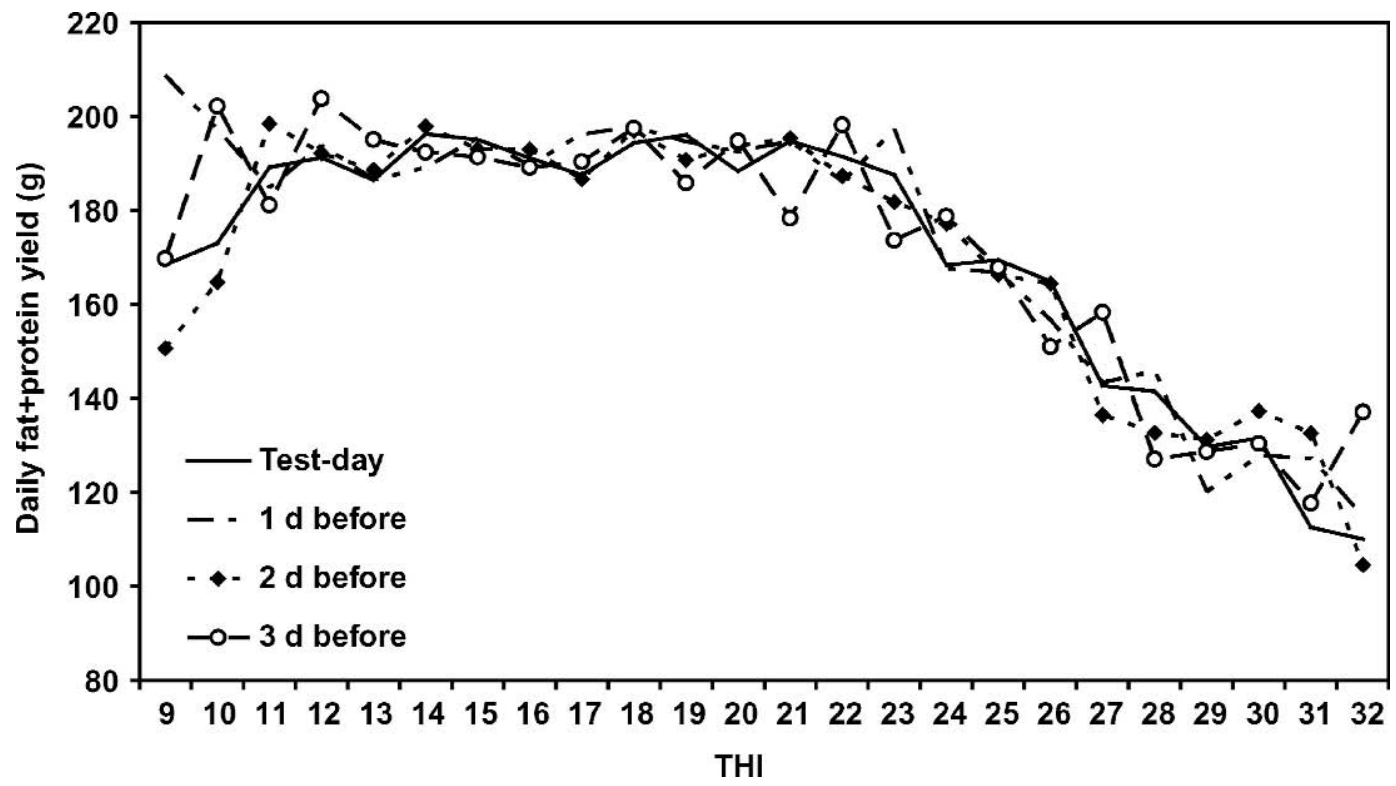

Figure 5. Relationship between the daily fat-plus-protein yield and the temperature-humidity index (THI) based on maximum temperature and average relative humidity in $4 \mathrm{~d}$ (test-day, and 1,2 , and $3 \mathrm{~d}$ before). 
Table 3. Coefficients of determination $\left(\mathrm{R}^{2}\right)$, root mean square errors (Root MSE), and production effects using various models and datasets for daily milk yield (g). Model 1 is shown with the full data set, and model 2 is shown with the full data set and the reduced data sets.

\begin{tabular}{|c|c|c|c|c|c|c|c|}
\hline & \multicolumn{7}{|c|}{ Weather period $^{1}$} \\
\hline & $0 \mathrm{~d}$ & $1 d$ & $2 \mathrm{~d}$ & $3 \mathrm{~d}$ & $0-1 d$ & $0-2 \mathrm{~d}$ & $0-3 \mathrm{~d}$ \\
\hline \multicolumn{8}{|l|}{ Model 1: Full data set } \\
\hline $\mathrm{R}^{2}$ & 0.543 & 0.550 & 0.546 & 0.548 & 0.545 & 0.544 & 0.550 \\
\hline Root MSE & 474.4 & 472.9 & 472.4 & 473.4 & 474.8 & 475.2 & 472.1 \\
\hline \multicolumn{8}{|l|}{ Model 2: Full data set } \\
\hline $\mathrm{R}^{2}$ & 0.540 & 0.545 & 0.539 & 0.546 & 0.544 & 0.545 & 0.547 \\
\hline Root MSE & 476.0 & 475.3 & 476.0 & 474.4 & 475.3 & 474.8 & 473.7 \\
\hline \multicolumn{8}{|l|}{ Model 2: Reduced data sets THI $\geq 23$} \\
\hline $\mathrm{R}^{2}$ & 0.607 & 0.625 & 0.610 & 0.630 & 0.628 & 0.626 & 0.628 \\
\hline Root MSE & 448.7 & 436.6 & 449.5 & 442.1 & 440.7 & 440.7 & 439.2 \\
\hline Production & -56.7 & -62.2 & -56.0 & -54.0 & -56.7 & -63.6 & -62.8 \\
\hline
\end{tabular}

${ }^{1}$ Weather periods: $0 \mathrm{~d}, 1 \mathrm{~d}, 2 \mathrm{~d}$, and $3 \mathrm{~d}$ represent test-day, and 1,2 , and $3 \mathrm{~d}$ before test-day, respectively; $0-1 \mathrm{~d}, 0-2 \mathrm{~d}$, and $0-3 \mathrm{~d}$ represent the $2-, 3-$, and 4 -d periods ending on the test-day, respectively.

follow a smooth downward trend, no matter which time period (single or multiple days) of weather was taken into consideration. The precise angle of the decline in yield was difficult to establish due to seemingly random fluctuations across $\mathrm{T}$ groups. This result was in agreement with the observations of Ravagnolo et al. (2000) in Holstein cattle.

Figures 4 and 5 show the least squares means for the entire data set for daily milk and for daily fatplus-protein production, respectively, in all $4 \mathrm{~d}$ considered. All lines show a similar shape for daily milk and fat-plus-protein production. Both traits appeared to begin to decline at approximately $\mathrm{THI}=23$; therefore, this value was considered the starting point of heat stress for the Valle del Belice dairy sheep. Similar figures for percentage traits are not shown; however, for fat percentage, a linear decline of $-0.09 \%$ per unit increase of THI was observed for THI up to 18 , above which point the fat percentage remained stable. Protein percentage showed a linear decline of $-0.03 \%$ per unit increase of THI over the entire scale. Therefore, these percentage traits did not appear to be affected by heat stress.

Coefficients of determination and root mean square errors obtained with model 1 and 2 in all periods are presented in Tables 3, 4, 5, and 6. For model 2, two data sets were used, the full data set considering the entire range of THI and the reduced data set containing records with $\mathrm{THI} \geq 23$. For each model-data set combination, all coefficients of determination, and all root mean square errors considering weather conditions of all single days and all longer periods were similar. The lag 1 serial correlations of $\mathrm{T}, \mathrm{RH}$, and THI were $0.96,0.84$, and 0.93 , respectively, indicating the stable nature of the weather in Sicily. The period of weather data taken into account might be more important in areas with more daily weather variation. All fixed effects were significant in all analyses for model 1 and 2 . The reduction in the number of weatherrelated parameters from the 2 -parameter $\mathrm{T} \times \mathrm{RH}$ inter-

Table 4. Coefficients of determination $\left(\mathrm{R}^{2}\right)$, root mean square errors (Root MSE), and production effects using various models and datasets for fat percentage. Model 1 is shown with the full data set, and model 2 is shown with the full data set and with the reduced data sets.

\begin{tabular}{|c|c|c|c|c|c|c|c|}
\hline & \multicolumn{7}{|c|}{ Period of weather } \\
\hline & od & $1 d$ & $2 \mathrm{~d}$ & $3 d$ & $0-1 d$ & $0-2 d$ & $0-3 \mathrm{~d}$ \\
\hline \multicolumn{8}{|c|}{ Model 1: Full data set } \\
\hline $\mathrm{R}^{2}$ & 0.311 & 0.307 & 0.307 & 0.306 & 0.302 & 0.304 & 0.306 \\
\hline Root MSE & 1.19 & 1.20 & 1.19 & 1.20 & 1.20 & 1.20 & 1.20 \\
\hline \multicolumn{8}{|c|}{ Model 2: Full data set } \\
\hline $\mathrm{R}^{2}$ & 0.305 & 0.305 & 0.303 & 0.309 & 0.309 & 0.305 & 0.312 \\
\hline Root MSE & 1.20 & 1.20 & 1.20 & 1.19 & 1.19 & 1.20 & 1.19 \\
\hline \multicolumn{8}{|c|}{ Model 2: Reduced data sets THI $\geq 23$} \\
\hline $\mathrm{R}^{2}$ & 0.364 & 0.410 & 0.389 & 0.389 & 0.382 & 0.390 & 0.390 \\
\hline Root MSE & 1.21 & 1.17 & 1.21 & 1.21 & 1.18 & 1.19 & 1.20 \\
\hline Production $(\%)$ & 0.01 & 0.01 & 0.02 & 0.04 & 0.00 & 0.00 & 0.00 \\
\hline
\end{tabular}

${ }^{1}$ Weather periods: $0 \mathrm{~d}, 1 \mathrm{~d}, 2 \mathrm{~d}$, and $3 \mathrm{~d}$ represent test-day, and 1,2 , and $3 \mathrm{~d}$ before test-day, respectively; $0-1 \mathrm{~d}, 0-2 \mathrm{~d}$, and $0-3 \mathrm{~d}$ represent the $2-, 3-$, and 4 -d periods ending on the test-day, respectively. 
Table 5. Coefficients of determination $\left(\mathrm{R}^{2}\right)$, root mean square errors (Root MSE), and production effects using various models and datasets for protein percentage. Model 1 is shown with the full data set, and model 2 is shown with the full data set and with the reduced data sets.

\begin{tabular}{|c|c|c|c|c|c|c|c|}
\hline & \multicolumn{7}{|c|}{ Weather period $^{1}$} \\
\hline & od & $1 d$ & $2 \mathrm{~d}$ & $3 \mathrm{~d}$ & $0-1 d$ & $0--2 d$ & $0-3 d$ \\
\hline \multicolumn{8}{|c|}{ Model 1: Full data set } \\
\hline $\mathrm{R}^{2}$ & 0.401 & 0.399 & 0.396 & 0.398 & 0.400 & 0.399 & 0.399 \\
\hline Root MSE & 0.71 & 0.71 & 0.71 & 0.71 & 0.71 & 0.71 & 0.71 \\
\hline \multicolumn{8}{|c|}{ Model 2: Full data set } \\
\hline $\mathrm{R}^{2}$ & 0.404 & 0.405 & 0.404 & 0.404 & 0.407 & 0.406 & 0.406 \\
\hline Root MSE & 0.70 & 0.71 & 0.70 & 0.71 & 0.70 & 0.70 & 0.70 \\
\hline \multicolumn{8}{|c|}{ Model 2: Reduced data sets THI $\geq 23$} \\
\hline $\mathrm{R}^{2}$ & 0.456 & 0.462 & 0.468 & 0.468 & 0.457 & 0.466 & 0.466 \\
\hline Root MSE & 0.73 & 0.71 & 0.72 & 0.73 & 0.73 & 0.73 & 0.73 \\
\hline Production (\%) & 0.00 & -0.01 & -0.01 & -0.01 & -0.01 & -0.01 & -0.01 \\
\hline
\end{tabular}

${ }^{1}$ Weather periods: $0 \mathrm{~d}, 1 \mathrm{~d}, 2 \mathrm{~d}$, and $3 \mathrm{~d}$ represent test-day, and 1,2 , and $3 \mathrm{~d}$ before test-day, respectively; $0-1 \mathrm{~d}, 0-2 \mathrm{~d}$, and $0-3 \mathrm{~d}$ represent the $2-, 3-$, and 4 -d periods ending on the test-day, respectively.

action in model 1 to the single-parameter THI in model 2 did not affect the coefficients of determination. For all traits, higher coefficients of determination were found with the reduced data set. This result was expected because the model was developed to handle heat stress, and heat stress was not observed for THI $<23$. For the reduced data set, changes in all traits per unit increase of THI $\geq 23$ are also shown (Final rows of Tables 3 to 6). For both milk and fat-plus-protein yields, among individual days, the greatest decrease in yield per unit of THI was observed for THI on the day before milk recording. Daily milk yield decreased by $62.2 \mathrm{~g}(-3.9 \%)$ per unit increase of $\mathrm{THI} \geq 23$ (Table 3 ). In a similar manner, Table 6 shows a decrease of daily fat-plus-protein production of about $-8.6 \mathrm{~g}$ $(-4.4 \%)$ per unit increase of THI $\geq 23$ at $1 \mathrm{~d}$ before the test-day. However, for both yield traits, the THI during 3 - and 4-d periods were associated with a larger yield decline per unit than THI on the single day prior. Tables 4 and 5 show that fat and protein percentages were unaffected by heat stress, inasmuch as no clear effect on these traits was observed for THI $\geq 23$. Heat stress, therefore, appears to reduce fat and protein yields in a similar proportion as overall milk yield. Furthermore, this result explains why root mean square errors of the reduced data sets were only lower for the yield traits.

The results indicate that Valle del Belice sheep, although originating from a hot environment, are affected by heat stress, resulting in a decrease of production. In this study we observed that heat stress affects production when THI $\geq 23$. This threshold is lower than that reported by Sevi et al. (2001) for the related Comisana dairy sheep breed. In their study, they reported that animals suffered from heat stress only when THI $\geq 27$. The differences are probably due to the availability of shade for animals in the study by Sevi et al. (2001), which likely increased the heat-stress threshold level. Furthermore, other factors, such as differences in methodology, breed, wind speed, and period

Table 6. Coefficients of determination $\left(R^{2}\right)$, root mean square errors (Root MSE) and production effects using various models and datasets for daily fat-plus-protein yield (g). Model 1 is shown with the full data set, and model 2 is shown with the full data set and with the reduced data sets.

\begin{tabular}{lccccccc}
\hline & \multicolumn{7}{c}{ Weather period $^{1}$} \\
\cline { 2 - 8 } & $0 \mathrm{~d}$ & $1 \mathrm{~d}$ & $2 \mathrm{~d}$ & $3 \mathrm{~d}$ & $0-1 \mathrm{~d}$ & $0-2 \mathrm{~d}$ & $0-3 \mathrm{~d}$ \\
\hline Model 1: Full data set & & & & & & & \\
$\quad \mathrm{R}^{2}$ & 0.504 & 0.514 & 0.510 & 0.509 & 0.509 & 0.509 & 0.514 \\
$\quad$ Root MSE & 55.3 & 55.0 & 55.0 & 55.2 & 55.2 & 55.2 & 54.9 \\
$\quad \begin{array}{l}\text { Model 2: Full data set } \\
\quad \mathrm{R}^{2}\end{array}$ & 0.501 & 0.511 & 0.504 & 0.507 & 0.507 & 0.510 & 0.513 \\
$\quad$ Root MSE & 55.5 & 55.1 & 55.3 & 55.3 & 55.3 & 55.1 & 55.0 \\
$\quad$ Model 2: Reduced data sets THI $\geq 23$ & & & & & & & \\
$\quad R^{2}$ & 0.525 & 0.558 & 0.537 & 0.553 & 0.553 & 0.553 & 0.554 \\
$\quad$ Root MSE & 50.1 & 48.5 & 49.9 & 50.2 & 49.0 & 48.6 & 48.6 \\
$\quad$ Production & -7.4 & -8.6 & -7.6 & -7.2 & -7.8 & -8.7 & -8.9 \\
\hline
\end{tabular}

${ }^{1}$ Weather periods: $0 \mathrm{~d}, 1 \mathrm{~d}, 2 \mathrm{~d}$, and $3 \mathrm{~d}$ represent test-day, and 1, 2, and $3 \mathrm{~d}$ before test-day, respectively; $0-1 \mathrm{~d}, 0-2 \mathrm{~d}$, and $0-3 \mathrm{~d}$ represent the $2-, 3$-, and 4 -d periods ending on the test-day, respectively. 
Table 7. Parameter estimates for daily milk production. ${ }^{1}$

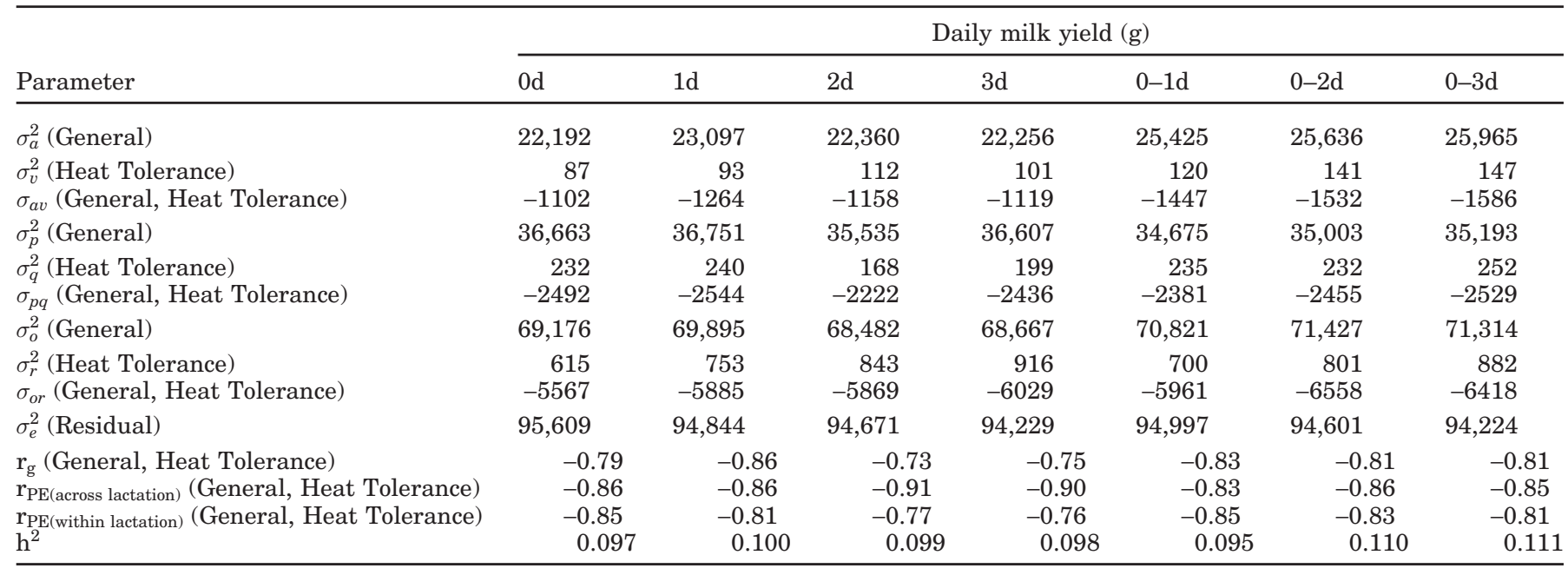

${ }^{1}$ Weather periods: $0 \mathrm{~d}, 1 \mathrm{~d}, 2 \mathrm{~d}$, and $3 \mathrm{~d}$ represent test-day, and 1,2 , and $3 \mathrm{~d}$ before test-day, respectively; 0-1d, 0-2d, and 0-3d represent the 2-, 3-, and 4-d periods ending on the test-day, respectively.

examined might have an effect. Srikandakumar et al. (2003) studied heat stress among Omani and Australian Merino sheep breeds reared in Oman. In that study, the animals demonstrated effects of heat stress when THI was $>32$.

Additive genetic variances for general and heat tolerance effects and the genetic correlation between these effects were estimated. Fat and protein percentages did not show an effect of heat stress and were omitted from the genetic analysis. An additional analysis was undertaken using an individual model in which the animal and across-lactation permanent environmental (co)variance components were modeled together, rather than separately, using an identity matrix instead of a relationship matrix. The sum of the nonresidual (co)variance components of this model differed by only $0.7 \%$ from those obtained with model 3 , hence results from model 3 appeared not to be affected by over-parameterization.

The estimates of variance components obtained using model 3 are presented in Tables 7 (milk) and 8 (fat-plus-protein). The additive genetic variance for heat tolerance was small in comparison to general additive genetic variance. The genetic correlations between general and heat tolerance additive effects were all negative in all periods considered for both daily

Table 8. Parameter estimates for daily fat-plus-protein production. ${ }^{1}$

\begin{tabular}{|c|c|c|c|c|c|c|c|}
\hline Parameter & \multicolumn{7}{|c|}{ Daily fat-plus-protein yield (g) } \\
\hline$\sigma_{a}^{2}($ General $)$ & 287 & 302 & 286 & 289 & 313 & 316 & 319 \\
\hline$\sigma_{a v}($ General, Heat Tolerance $)$ & -16 & $-1 \overline{9}$ & -16 & -16 & $-1 \overline{9}$ & $-2 \overline{1}$ & $-2 \overline{1}$ \\
\hline$\sigma_{p}^{2}($ General $)$ & 474 & 474 & 473 & 482 & 463 & 469 & 476 \\
\hline$\sigma_{q}^{2}($ Heat Tolerance $)$ & 2 & 2 & 2 & 2 & 2 & 2 & 3 \\
\hline$\sigma_{o}^{2}($ General $)$ & 944 & 966 & 947 & 954 & 971 & 981 & 983 \\
\hline$\sigma_{r}^{2}$ (Heat Tolerance) & 7 & 9 & 9 & 11 & 8 & 9 & 10 \\
\hline$\sigma_{o r}($ General, Heat Tolerance) & -78 & -84 & -82 & -86 & -84 & -88 & -90 \\
\hline$\sigma_{e}^{2}($ Residual $)$ & 1336 & 1327 & 1327 & 1320 & 1329 & 1325 & 1321 \\
\hline $\mathrm{r}^{\mathrm{g}}$ (General, Heat Tolerance) & -0.77 & -0.82 & -0.75 & -0.75 & -0.79 & -0.77 & -0.77 \\
\hline $\mathrm{r}_{\mathrm{PE}(\text { across lactation) }}($ General, Heat Tolerance) & -0.94 & -0.94 & -0.96 & -0.99 & -0.95 & -0.96 & -0.96 \\
\hline
\end{tabular}

${ }^{1}$ Weather periods: $0 \mathrm{~d}, 1 \mathrm{~d}, 2 \mathrm{~d}$, and $3 \mathrm{~d}$ represent test-day, and 1,2 , and $3 \mathrm{~d}$ before test-day, respectively; $0-1 \mathrm{~d}, 0-2 \mathrm{~d}$, and $0-3 \mathrm{~d}$ represent the 2-, 3-, and 4-d periods ending on the test-day, respectively. 
milk (Table 7) and fat-plus-protein (Table 8) production. The negative correlations show that daily milk and fat-plus-protein yield are antagonistically related to heat tolerance. In hot climates, selection for milk production traits should therefore include heat tolerance, to avoid animal performance and welfare degradation. Furthermore, economically affordable management measures for reducing heat stress should be considered.

\section{CONCLUSIONS}

The results indicate that Valle del Belice sheep, although originating from a hot environment, are affected by heat stress starting at THI $=23$, and this results in a decrease of production yields. Milk composition traits do not appear to be affected by heat stress. Due to the stable nature of the Sicilian weather, little difference was found between the effects of weather measurements on different days before the milk recording; however, use of a period of several days before the day of milk recording seems optimal. The results imply that genetics for yield traits are antagonistic with heat tolerance and, therefore, single-trait selection for yields will result, in the long term, in animals with lower heat tolerance. Therefore, the use of heatresistant individuals in a sheep breeding program should be one of the main strategies to improve animal welfare and productivity in hot climates. The genetic results reported here are in agreement with those obtained by Ravagnolo and Misztal (2000) for Holstein dairy cattle.

\section{ACKNOWLEDGMENTS}

Authors wish to thank the "Ufficio Centrale di Ecologia Agraria" of the Italian Ministry of Agriculture and Forestry for providing the meteorological data. The second author of this manuscript had a Marie Curie Fellowship of the European Community program "Quality of Life" under contract number QLK5CT-2001-51892 during this research.

\section{REFERENCES}

Ames, D. R., J. E. Nellor, and T. Adams. 1971. Energy balance during heat stress in sheep. J. Anim. Sci. 32:784-788.
Barillet, F., and D. Boichard. 1994. Use of first-lactation test day data for genetic evaluation of Lacaune dairy sheep. Pages 111114 in Proc. 5th World Congr. Genet. Appl. Livest. Prod., Guelph, Canada.

Bianca, W. 1962. Relative importance of dry and wet bulb temperature in causing heat stress in cattle. Nature 195:251-252.

Carta, A., S. R. Sanna, and S. Casu. 1995. Estimating lactation curves and seasonal effects for milk, fat and protein in Sarda dairy sheep with a test day model. Livest. Prod. Sci. 44:37-44.

FAO trade yearbook. 1997. Production yearbook. Vol. 51. FAO Publ., Rome, Italy.

Finch, V.A. 1984. Heat as a stress factor in herbivores under tropical conditions. Pages 89-105 in Herbivore Nutrition in the Subtropics and Tropics. F. M. C. Gilchrist, and R. I. Mackie, ed. The Science Press, Craighall, South Africa.

Hayes, B. J., M. Carrick, P. Bowman, and M. E. Goddard. 2003. Genotype $\times$ environment interaction for milk production of daughters of Australian dairy sires from test-day records. J. Dairy Sci. 86:3736-3744.

Johnson, H. D., A. C. Ragsdale, I. L. Berry, and M. D. Shanklin. 1962. Effect of various temperature humidity combinations on milk production of Holstein cattle. Missouri Agric. Exp. Sta. Res. Bull. 791:1-39. Univ. of Missouri, Columbia, MO.

Kelly, C. F., and T. E. Bond. 1971. Bioclimatic factors and their measurement: A guide to environmental research on animals. National Academy of Sciences, Washington, DC.

Ligda, C., G. Gabriilidis, T. Papadopoulos, and A. Georoudis. 2000. Estimation of genetic parameters for production traits of Chios sheep using a multitrait animal model. Livest. Prod. Sci. 66:217-222.

Lowe, T. E., C. J. Cook, J. R. Ingram, and P. J. Harris. 2001. Impact of climate on thermal rhythm in pastoral sheep. Physiol. Behav. 74:659-664.

McDowell, R. E. 1972. Improvement of livestock production in warm climates. W. A. Freeman and Co., San Francisco, CA.

Misztal, I., S. Tsuruta, T. Strabel, B. Auvray, T. Druet, and D. H. Lee. 2002. BLUPF90 and related programs (BGF90). CD-ROM commun. no. 18-20 in Proc. 7th World Congr. Genet. Appl. Livest. Prod., Montpellier, France.

Ptak, E., and L. R. Schaeffer. 1993. Use of test day yields for genetic evaluation of dairy sires and cows. Livest. Prod. Sci. 34:23-34

Ravagnolo, O., and I. Misztal. 2000. Genetic component of heat stress in dairy cattle, parameter estimation. J. Dairy Sci. 83:2126-2130.

Ravagnolo, O., I. Misztal, and G. Hoogenboom. 2000. Genetic component of heat stress in dairy cattle, development of heat index function. J. Dairy Sci. 83:2120-2125.

SAS Institute. 2000. User's Guide, Version 8. SAS Institute, Inc., Cary, NC.

Sevi, A., G. Annicchiarico, M. Albezio, L. Taibi, A. Muscio, and S. Dell'Aquila. 2001. Effects of solar radiation and feeding time on behavior, immune response, and production of lactating ewes under high ambient temperature. J. Dairy Sci. 84:629-640.

Srikandakumar, A., E. H. Johnson, and O. Mahgoub. 2003. Effect of heat stress on respiratory rate, rectal temperature, and blood chemistry in Omani and Australian Merino sheep. Small Rumin. Res. 49:193-198. 